\title{
Ecologically Sensitive Areas and Coastal Geomorphological Features of Andaman \& Nicobar Islands, India
}

\author{
R Sridhar* \\ National Centre for Sustainable Coastal Management, Ministry of Environment, Forest and Climate Change, Anna University Campus, India \\ Received: 㠿 May 07, 2018; Published: 眥 May 14, 2018 \\ *Corresponding author: R Sridhar, National Centre for Sustainable Coastal Management, Ministry of Environment, Forest and Climate \\ Change, Anna University Campus, India
}

\begin{abstract}
Andaman and Nicobar Islands (ANI) are a group of remote, isolated island archipelago and external territory of India at the juncture of the Bay of Bengal and Andaman Sea extending between $92^{\circ}$ to $94^{\circ}$ East and $6^{\circ}$ to $14^{\circ}$ North latitude. This article summarise various ecologically sensitive areas of ANI for the purpose of conservation through the applicable regulatory mechanisms. This will help the Andaman Administration in implementation of the Island Protection Zone (IPZ) Notification, 2011 issued under the Environment (Protection) Act, 1986.
\end{abstract}

Keywords: Andaman and Nicobar; Islands; Ecologically Sensitive Areas; Coast; Marine.

\section{Introduction}

The coastal and marine environments of the Andaman and Nicobar Islands (ANI) cover coral reefs, sea grass beds which support dugong, an extensive network of mangrove creeks inhabited by crocodiles, a variety of other reptiles, fish, birds and invertebrates and essential turtle nesting beaches. The Mahatma Gandhi Marine National Park and Rani Jhansi Marine National Park are important Marine Protected Areas in ANI. The brief information about various Ecologically Sensitive Areas is given below:

Mangroves: The total mangrove cover in ANI as per the FSI Assessment, 2011 is $617 \mathrm{~km} 2$. The mangrove forest of ANI is encountered along sea coast, creeks and close to beaches. The long but irregular and deeply indented coastline of the islands, result in innumerable creeks and bays which facilitate the development of rich and extensive mangrove forests. Tall dense mangrove forest occurs in these islands due to favourable climatic conditions such as short dry season, high tidal fluctuation and heavy amount of rainfall (Blasco \& Aizpuru [1]; Dagar et al. [2]; Naskar \& Mandal [3]). The major true mangrove species encountered in ANI are Scyphiphora hydrophyllacea, Cynometra iripa, Avicennia marina, A. officinalis, Excoecaria agallocha, Bruguiera cylindrica, B. gymnorrhiza, B. parviflora, B. sexangula, Ceriops tagal, Rhizophora apiculata, $R$. mucronata, R. stylosa, Heritiera littoralis, Lumnitzera littorea,
L. racemosa, Sonneratia alba, S. caseolaris, S. ovata, Aegicera scorniculatum, Xylocarpus granatum, Nypa fruticans and Phoenix paludosa (SAC, [4]).

Coral Reefs: Coral reefs of the ANI cover an area of about 1020 sq.km i.e. $6 \%$ of the total continental shelf of these islands (SAC, [4]). The corals are in the form of fringing, patchy and barrier reefs. The common genera contributing to the reef formation in these islands are Acropora, Montipora, Pocillopora, Porites, Goniopora, Favia, Echinopora, Fungia, Milleporina and Heliopora. The earthquake and the consequent tsunami which struck these islands in December 2004 caused vast devastation of coral reefs leading to geomorphological changes, resulting in uplifting and exposure of reefs in the northern Andaman Islands.

Sand Beaches, Sand Dunes and Mudflats: ANI have sand beaches of various dimensions and in some of the islands beaches are formed out of coral sand while in others it is due to rock weathering. According to a wetland map prepared by the Space Application Center [4], Ahmedabad, using satellite remote sensing data, a total of 63,033 ha is covered under the sand/beach of the coastal wetland of India. The coastal land use area of A\&N estimated by SAC shows that the total area under sandy area /saline area is $34.82 \mathrm{sq} . \mathrm{km}$ and beach area is $40.01 \mathrm{sq} . \mathrm{km}$ [4]. Mudflats are 
the most non vegetated areas that are alternately exposed and inundated by the falling and rising of the tide. Based on the wetland map prepared by the SAC, an area of 5,858 ha has been occupied by intertidal mud flats in the Andaman, whereas in the Nicobar, the intertidal mud flats occupy 6541 ha of total wetland area [4].

Protected Areas: To protect and conserve the fauna and flora of these islands, many Protected Areas (PAs), both terrestrial and marine, have been constituted under the Wild Life Protection Act. At present there are nine National Parks and 96 Sanctuaries which have been established in these islands. Most of these PAs are small isolated islands. The PAs of marine areas are, MGMNP, RJMNP and Cinque Islands, Lohabarrack, Cuthburt Bay, North Reef and Galathea Bay Sanctuaries and parts of Great Nicobar Biosphere Reserve.

Salt Marshes: Salt Marsh is a relatively flat tide influenced area of the shore where fine sediment is deposited and salt tolerant grasses grow (Trujillo and Harold Thurman, [5]). According to a wetland map prepared by the SAC using satellite remote sensing data, a total of 1, 61,144 ha are covered under the salt marsh of the coastal wetland of India. Of which, an area of 6,029 ha is distributed in the ANI.

Turtle Nesting Grounds: There are four species of marine turtles reported around the ANI, which include the leatherback turtle (Dermochelys coriacea), the hawksbill turtle (Eretmochelys imbricata), the green sea turtle (Cheloniamydas) and the Olive Ridley (Lepidochely olivacea) (Andrews \& Tripathy, 2004). Studies in the Andaman and Nicobars have recorded India's best nesting beaches for three species, the Leatherback, Green and Hawksbill sea turtles. Turtle nesting mainly reported at Kalipur beach, Diglipur, Ramanagar Beach at Diglipur and Karmatang beach at Mayabunder. In 1978 the notification of 94 islands in the Andamans as Sanctuaries includes 30 islands as confirmed sea turtle nesting sites. There are at least 24 sites reported for the Nicobar group of islands (Bhaskar, [6] and Tiwari, [7]). Currently most of the nesting sites in ANI are either in Tribal Reserves or in uninhabited islands.

Horse Shoe Crab habitats: So far, habitats for Horse shoe crabs have not been reported in ANI. In India, the distribution of the horseshoe crabs namely Tachypleus gigas and Carcinoscorpius rotundicauda is restricted to north east coast of Orissa and Sunderbans area of the West Bengal respectively (Chatterji \&Abidi [8]).

Sea grass and seaweed beds: In India, the maximum extent of seagrass occurs were reported along the Gulf of Mannar and Palk Bay and Andaman and Lakshadweep group of Islands. Out of the 14 sea grass species reported from India, 9 species of sea grass are reported from Andaman and Nicobar Islands. In Andaman coast three mangrove associated seagrass are Thalassia hemprichii, Enhalus acoroides and Halophila avails producing a biomass up to 1941 gwetwt $/ \mathrm{m}^{2}$ (Bindu Sulochanan, [[9]). Seaweeds have been reported in most of the islands including South Andaman islands, Middle and North Andaman islands and Great Nicobar island.
Nesting ground of birds: ANI have been designated as one of the "Endemic Bird Areas" of the world (statterfield et al. [10]; Islam \& Rahmani, [11]; Sankaran [12], [13], [14]). Due to isolation from the mainland, the endemism is very high in all taxa including avifauna. Among the Avifauna, 270 species and subspecies have been reported from ANI so far, 126 within Andaman and 50 for the Nicobars (Sankaran \& Vijayan, [15]; Islam \& Rahmani, [11]). The rich tropical forests support many endemic bird species, including the threatened Nicobar Megapode Megapodius nicobariensis, Narcondam Hornbill Aceros narcondami and Nicobar Bulbul Hypsipetes nicobariensis.

Fishing villages and areas of traditional rights: Fisheries form one of the most natural resources of the islands. There is no traditional fisher community in the Islands. Fishermen from West Bengal, Andhra Pradesh, Kerala and Tamil Nadu have migrated to these islands either through settlement schemes of the Government or voluntarily. According to the National Marine Fisheries Census 2005, there are 103 fishing villages and 25 fish landing centres in ANI. In view of the potential and scope for development, fisheries are considered as a thrust sector for the overall development of the Islands. Over 1,368 species of fishes, 580 species of crustaceans, 900 species of mollusks and 300 species of echinoderms occur in the island waters, of which, 350 species of fishes are commercially important (Krishnamurthy \& Soundarajan, [16]).

\section{Conclusion}

The coastal and marine ESAs are under pressure on account of increased anthropogenic activity on the coast, as a result of globalization. It is necessary to protect these coastal ecosystems to ensure sustainable development. In order to protect these ESAs from the developmental and industrial activities, they have been brought under ICRZ-I (a) classification of the IPZ Notification 2011, where no new construction shall be permitted. While preparing the mandatory ICRZ and IIM Plan for ANI, the ESAs have to be taken into consideration carefully. Several studies have been carried out to assess and map various ESAs. There is a need to assess the current status of ecology of various ESAs and identify and demarcate other areas as ecologically sensitive, based on scientific criteria, in addition to ESAs already mentioned in the IPZ Notification. Mapping, delineation and demarcation of the ESAs along the coast appear as challenges in the coastal zone management as they would need lot of debates in implementation at ground level. Sufficient baseline data would help in preparing proper CRZ mapping by which the prohibitory and regulatory activities would hopefully be adhered to and which lead to proper implementation of IPZ Notification.

\section{References}

1. Blasco F, Aizpuru M (1997) Classification and evolution of the mangroves of India. Tropical Ecol. 38: 357-374.

2. Dagar JC, Mongia AD, Bandhopadhyaya AK (1991) Mangroves of Andaman and Nicobar Islands. Oxford \& IBH, Bombay.

3. Naskar KR, Mandal RN (1999) Ecology and Biodiversity of Indian Mangroves. New Delhi: Daya Publishing House 754 pp. 
4. SAC (2011) National Wetland Atlas: Andaman \& Nicobar Islands. SAC/ RESA/AFEG/NWIA/ATLAS/04/2011, Space Applications Centre (ISRO) India $\mathrm{p} 190$

5. Trujillo AP, Thurman HV (2011) Essentials of Oceanography" $\left(10^{\text {th }}\right.$ edn.), Pear Educ, Prentice Hall.

6. Bhaskar S (1993) The status and ecology of sea turtles in the Andaman and Nicobar Islands. Publication no ST 1993. Centre for Herpetology/ Madras Crocodile Bank Trust, India 20 pp.

7. Tiwari M (1991) A follow up sea turtle survey in the southern Nicobars. Report to the Andaman and Nicobar Islands Forest Department and Madras Crocodile Bank Trust.

8. Chatterji A, Abidi SAH J (1993) The Indian horseshoe crab: a living fossil. J Indian Ocean Stud 1: 43-48

9. Sulochanan B (2012) Sea grass distribution and its vulnerability in India. CMFRI, Teaching Resource p. 18-23.

10. Statterfield AJ, Crosby MC, Long AJ, Wege DC (1998) Endemic Bird Areas of the World. Birdlife International Cambridge, UK.
11. Islam MZ, Rahmani AR (2004) Important bird areas in India: Priority sites for conservation. Indian Bird Conservation Network. Bombay natural History Society \& Birdlife International (UK) pp. 89-135.

12. Sankaran R (1993) The avifauna of the Andaman and Nicobar review and the current scenario. Ornithological Society of India, India.

13. Sankaran R (1995) The Nicobar Megapode and other endemic avifauna of the Nicobar Islands. SACON Technical Report No 2 SACON, India.

14. Sankaran R (1996) Developing a protected area network in the Islands: the perspective of endemic avifauna. Salimali Centre for Ornithology and Natural History, India.

15. Sankaran R, Vijayan L (1993) The avifauna of the Andaman and Nicobar Islands: a review of and the current scenario Pp 225-271. In, A Verghese, S Sridhar, AK Chakravarthy (Eds.) Bird Conservation Strategies for the Nineties and Beyond. Ornithological Society of India, India.

16. Krishnamurthy V, Soundarajan R (1999) R \& D needs for promotion of fisheries in Andaman and Nicobar Islands. Seafood Export J 30(2): 4144.

\section{(c) (i) \\ This work is licensed under Creative \\ Commons Attribution 4.0 License}

To Submit Your Article Click Here:

Submit Article
DOI: $10.32474 /$ MAOPS.2018.01.000119

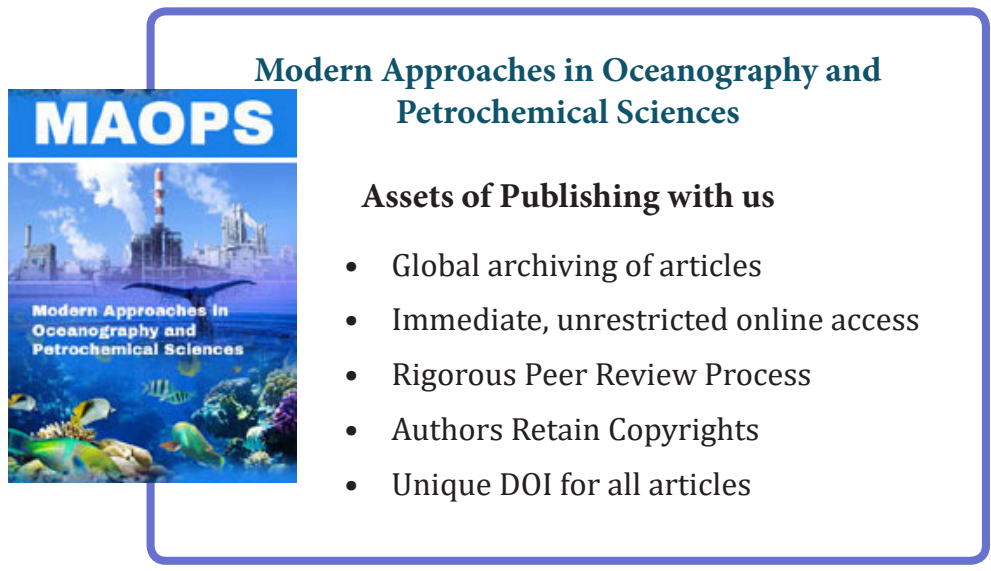

